ISSN 1678-3921

Journal homepage: www.embrapa.br/pab

For manuscript submission and journal contents, access: www.scielo.br/pab
Welson Lima Simões ${ }^{(1)}$, Anderson Ramos de Oliveira ${ }^{(1)}($, Moises Alves de Souza(2) Verônica Massena Reis ${ }^{(3)}$ and Paulo Ivan Fernandes-Júnior ${ }^{(1 \otimes)}$

(1) Embrapa Semiárido, BR-428, Km 152, Zona Rural, Caixa Postal 23, CEP 56302-970 Petrolina, PE, Brazil.

E-mail: welson.simoes@embrapa.br, anderson.oliveira@embrapa.br. paulo.ivan@embrapa.br

(2) Universidade do Estado da Bahia, Departamento de Tecnologias e Ciência Sociais, Avenida Dr. Chastinet Guimarães, s/no, São Geraldo,

CEP 48900-000 Juazeiro, BA, Brazil.

E-mail: moisesalves-1989@hotmail.com

(3) Embrapa Agrobiologia, Rodovia BR-465, Km 7, Ecologia, Caixa Postal 74505, CEP 23891-000 Seropédica, RJ, Brazil. E-mail: veronica.massena@embrapa.br

$\bowtie$ Corresponding author

Received

October 24, 2018

Accepted

September 6, 2019

How to cite

SIMÕES, W.L.; OLIVEIRA, A.R. de; SOUZA,

M.A. de; REIS, V.M.; FERNANDES-JÚNIOR,

P.I. Efficient inoculation of diazotrophic bacteria into sugarcane by the drip irrigation system. Pesquisa Agropecuária Brasileira, v.54, e01110, 2019. DOI: https://doi.org/10.1590/ S1678-3921.pab2019.v54.01110.

\section{Efficient inoculation of diazotrophic bacteria into sugarcane by the drip irrigation system}

\begin{abstract}
The objective of this work was to assess the efficiency of the inoculation of a diazotrophic bacterial consortium by the drip irrigation system into sugarcane (Saccharum spp.), in the Brazilian semiarid region. The evaluated treatments were: standard inoculation by submersion; one or two inoculations by drip irrigation; nitrogen (urea) applied by fertigation; and negative controls, without inoculation or nitrogen fertilization. Leaf gas exchanges and plant growth and yield were assessed. Inoculation by irrigation is efficient for all variables, and double inoculation by the drip irrigation system stands out, increasing stem yield in $16 \%$ when compared with the negative control, without differing from the treatment with nitrogen fertilizer.
\end{abstract}

Index terms: biological nitrogen fixation, Brazilian semiarid region, inoculant, plant-growth promoting bacteria.

\section{Inoculação eficiente de bactérias diazotróficas via sistema de irrigação por gotejamento em cana-de-açúcar}

Resumo - O objetivo deste trabalho foi avaliar a eficiência da inoculação de um consórcio de bactérias diazotróficas por meio do sistema de irrigação por gotejamento em cana-de-açúcar (Saccharum spp.), em região semiárida brasileira. Os tratamentos avaliados foram: inoculação padrão por submersão; uma ou duas inoculações por irrigação por gotejamento; ureia aplicada por fertirrigação; e controles negativos, sem inoculação ou fertilização com nitrogênio. Avaliaram-se as trocas gasosas foliares e o crescimento e a produtividade das plantas. A inoculação por irrigação é eficiente para todas as variáveis, com destaque para a dupla inoculação pelo sistema de irrigação por gotejamento, que aumentou a produtividade de colmos em $16 \%$ quando comparado ao controle negativo, não tendo diferido do tratamento nitrogenado com ureia.

Termos para indexação: fixação biológica de nitrogênio, semiárido brasileiro, inoculante, bactérias promotoras do crescimento de plantas.

The sugarcane (Saccharum spp.) crop covers about 10 million hectares in Brazil, with an average yield of 70 tons per hectare (Conab, 2017). For the production of sustainable renewable fuels, it represents the most promising crop, since ethanol is considered the best alternative to petroleum-based fuels, such as gasoline and diesel. For high-yield sugarcane production systems, it is important to invest in improving 
plant nutrition, consequently increasing production costs.

In the field, sugarcane can efficiently associate with nitrogen-fixing bacteria (Urquiaga et al., 2012; Beneduzi et al., 2013). The use of inoculants containing the selected bacterial isolates, for example, can increase the rates of fixed nitrogen (Schultz et al., 2014; Pereira et al., 2019) and alter the activity of nitrogen-assimilation enzymes (Santos et al., 2017, 2019b), reducing the demands for nitrogenbased fertilizers, reducing the production costs. Besides fixing nitrogen, the bacteria associated with sugarcane can improve plant establishment in the field, acting through several mechanisms such as plant hormone production, insoluble nutrient (mainly phosphorus and iron) release, and biological control of pests and diseases, among others. In Brazil, a mixed inoculant containing five different nitrogenfixing species (Gluconacetobacter diazotrophicus, Nitrospirillum amazonense, Herbaspirillum seropedicae, Herbaspirillum rubrisubalbicans, and Paraburkholderia tropica) was recently developed for sugarcane, and its agronomic efficiency has already been proven (Silva et al., 2009; Schultz et al., 2014).

The responses to the inoculation of diazotrophic bacteria into sugarcane depend on the inoculation technology adopted. Some inoculation strategies such as the use of different inoculant carriers (Silva et al., 2009), immersion of stalks in inoculant solution (Schultz et al., 2014), and inoculation of pre-germinated sugarcane seedlings (Santos et al., 2019a) - have already been assessed, achieving different results. Currently, the immersion of sugarcane stalks in the inoculant solution is the standard procedure, but it is a laborious and unfeasible practice because inoculation can only be carried out at planting. Therefore, it is necessary to improve the systems for bacterial delivery into sugarcane, along with other practices, including irrigation.

Drip irrigation is a localized water-saving irrigation system, mainly via subsurface tubes, which is used in sugarcane fields in the Brazilian semiarid (Simões et al., 2015). The efficient bacterial delivery by irrigation water in the furrow (Gault et al., 1994) and by drip irrigation systems (Janat \& Kurdali, 2008) has already been reported for legume crops, but not for grasses. For corn (Zea mays L.), the inoculation of Azospirillum brasilense by sprinkling water was efficient to promote plant development (Costa et al., 2015), opening the possibility of new practices for the delivery of diazotrophic bacteria into grasses. Despite its importance for the Brazilian agriculture, there are no data regarding the optimization of sugarcane inoculation in the field through irrigation systems.

The objective of this work was to assess the efficiency of the inoculation of a diazotrophic bacterial consortium by the drip irrigation system into sugarcane, in the Brazilian semiarid region.

The experiment was conducted in the Mandacaru experimental field, located at Embrapa Semiárido, in the municipality of Juazeiro, in the state of Bahia, Brazil $\left(09^{\circ} 23^{\prime} 33^{\prime \prime} \mathrm{S}, 40^{\circ} 25^{\prime} 03^{\prime \prime} \mathrm{W}\right.$, at $365 \mathrm{~m}$ altitude) on a clayey Vertissolo Háplico, according to the Brazilian soil classification system (Santos et al., 2013), i.e., Vertisol Udert. The climate of the region is of the BSwh type, according to the Köppen-Geiger classification. The experiment was implemented in September 2013 and conducted until November 2015. During the 2014 and 2015 crop years, the average temperatures were 26.2 and $27.0^{\circ} \mathrm{C}$, respectively. In 2014, rainfall was concentrated from January to April and from November to December (490.7 mm), and, in 2015, from January to April (268.4 mm).

The chemical analyses of a composite soil sample were conducted according to Claessen (1997) and showed: $\mathrm{pH} 8.0,0.4 \mathrm{mS} \mathrm{cm}^{-1}$ electrical conductivity, $14.6 \mathrm{~g} \mathrm{~kg}^{-1}$ organic carbon, $9.6 \mathrm{mg} \mathrm{dm}^{-3} \mathrm{P}, 0.1 \mathrm{mg} \mathrm{dm}^{-3} \mathrm{~K}$, $24.8 \mathrm{cmol}_{\mathrm{c}} \mathrm{dm}^{-3} \mathrm{Ca}, 3.6 \mathrm{cmol}_{\mathrm{c}} \mathrm{dm}^{-3} \mathrm{Mg}, 0.0 \mathrm{cmol}_{\mathrm{c}} \mathrm{dm}^{-3}$ $\mathrm{Al}$, and base saturation of $97.8 \%$. The soil was prepared with plowing, and fertilization was carried out using $30 \mathrm{~kg} \mathrm{ha}^{-1} \mathrm{P}_{2} \mathrm{O}_{5}$ and $60 \mathrm{~kg} \mathrm{ha}^{-1} \mathrm{~K}_{2} \mathrm{O}$ splitted in two applications, at the planting and 80 days after planting. For cane-ratoon, the aplications of $\mathrm{K}$ and $\mathrm{P}$ were repeated, as described in the planting.

The sugarcane variety used was VAT 90212 due to its adaptation to the semiarid climatic conditions (Simões et al., 2015). Uniform cuttings (three buds) were selected as propagative material. The $12 \times 8-\mathrm{m}$ experimental plots consisted of four double rows, with $0.7 \mathrm{~m}$ between plants in the same row and $1.3 \mathrm{~m}$ between double rows. The useful area was considered as the middle $4 \mathrm{~m}$ of the two central lines of each plot. The adopted irrigation system was the subsurface drip irrigation at a depth of $0.2 \mathrm{~m}$, with drippers of $1.6 \mathrm{~L} \mathrm{~h}^{-1}$ spaced $0.5 \mathrm{~m}$ apart. Daily irrigation was applied based on crop evapotranspiration, considering the reference 
evapotranspiration obtained in a meteorological station, located in the same experimental field, by the Penman-Monteith method (Allen et al., 1998). The experiment was evaluated during two crop cycles: cane-plant in 2014 and first cane-ratoon in 2015.

The inoculant contained a bacterial consortium $G$. diazotrophicus (strain $\mathrm{Pal}^{\mathrm{T}}$ ), $N$. amazonense (Cbamc), H. seropedicae (HRC54), H.rubrisubalbicans (HCC103), and P. tropica $\left(\mathrm{PPe}^{\mathrm{T}}\right)-$, whose agronomic performance has already been proven (Silva et al., 2009; Schultz et al., 2014; Pereira et al., 2019). For inoculations by the drip irrigation system (ISI), a bacterial solution was prepared containing $3.75 \mathrm{~kg}$ peat-based inoculants at the concentration of $10^{9}$ cells per gram ( $0.75 \mathrm{~kg}$ for each bacteria), being dissolved and homogenized in $500 \mathrm{~L}$ irrigation water, collected at the São Francisco River. The inoculant mixtures were filtered in a cotton cloth, homogenized for 20 min, and then applied in the irrigation lines. The inoculation of cuttings by submersion in the bacterial solution (SSI) at sowing was conducted according to Silva et al. (2009). The evaluated treatments were: SSI; SSI + 1 ISI six months after planting; 1 ISI two months after planting; 2 ISI two and six months after planting; $120 \mathrm{~kg} \mathrm{ha}^{-1}$ urea-N applied by fertigation, split in two applications per cycle; and negative control, without inoculation or $\mathrm{N}$ fertilization. For the SSI treatment in the second cycle, the inoculation with the bacterial consortium was carried out using a backpack sprayer on the twentieth day after cane-plant harvest. For all ISI treatments, the inoculations by irrigation system were repeated in the ratoon-cane cycle.

Leaf gas exchanges were evaluated at 12 and 23 months after planting, for the cane-plant and ratooncane cycles, respectively. Net photosynthesis, stomatal conductance, transpiration, and leaf temperature were assessed using the LI-6200 portable infrared gas analyzer (LI-COR, Lincoln, NE, USA). The applied light intensity was $2,500 \mu \mathrm{mol} \mathrm{m} \mathrm{m}^{-2}$, and evaluations were carried out between 9 and 11 a.m., 20 hours after irrigation. The middle section of the blade portion of the third fully-expanded leaf was evaluated.

The biometric parameters assessed were plant height, number of leaves, stem diameter, and number of stems. Yield was considered the total weight of stems after leaf removal. The experimental design was a randomized complete block, with four blocks, in a $6 \times 2$ (treatments $\mathrm{x}$ crop cycles) factorial arrangement.
The data were analyzed by the analysis of variance, and means were compared by Tukey's test, at 5\% probability. Data presented as a single average for both cycles were not significant for interaction between treatments and crop cycle.

Differences in the gas exchanges were observed in the different treatments and crop cycles. Leaf temperature was only affected by the applied treatments, with no significant inoculation $\mathrm{x}$ crop cycle interaction or significance of the crop cycle (Table 1). There was a higher photosynthetic activity in the ratoon-cane cycle, for all treatments, and 1 ISI stood out in the two crop cycles, showing values higher than those of the negative control in both cycles, than SSI and N fertilization in the cane-plant cycle, and than SSI + 1 ISI and 2 ISI in the ratoon-cane cycle. For stomatal conductance, treatments SSI + 1 ISI and 1 ISI stood out in the cane-plant and ratoon-cane cycles, respectively, both with higher values than the negative control. The transpiration rates were higher for the SSI +1 ISI treatment in the cane-plant cycle, compared with those of the two inoculation treatments and the noninoculated controls. On average, leaf temperature was lower for 2 ISI than for SSI and the negative control.

Overall, inoculation by irrigation treatments in the field led to the best physiological conditions in sugarcane, indicating its better adaption to the environmental conditions of the Brazilian semiarid region. Alterations in sugarcane physiological behavior due to the inoculation of diazotrophic bacteria have already been assessed in greenhouse conditions (Medeiros et al., 2012; Santos et al., 2019b), but not in the field until now. Both in the cane-plant and ratooncane cycles, a lower net photosynthesis and stomatal conductance were observed in the negative control treatment, when sugarcane stomata were closed to reduce water loss, indicating a better adaptation of the inoculated plant, whose stomata was kept open, allowing gas exchange.

Regarding plant growth and yield parameters, positive interactions were observed for number of leaves and plant height (Table 2). There was a higher number of leaves in plants subjected to SSI than to $\mathrm{N}$ fertilization in the cane-plant cycle, with no differences in the ratoon-cane cycle. Moreover, except for $\mathrm{N}$ fertilization, all treatments had a higher number of leaves in the cane-plant cycle. When comparing 
both cycles, similar results were found for plant height - the inoculated plants, as well as the negative control, showed higher values for the first cycle. For the caneplant cycle, there was a higher plant growth in SSI, $\mathrm{SSI}+1$ ISI, and 2 SSI than in the treatment with $\mathrm{N}$ fertilization, also with no significant differences in the ratoon-cane cycle.

The inoculation of diazotrophic bacteria can increase sugarcane growth parameters in experiments in pots and in the field (Schultz et al., 2014; Simões et al., 2018). Under greenhouse conditions, for example, there was a positive increase in plant biomass and height with the inoculation by sprinkling water of the same bacterial consortium used in the present study into sugarcane (Simões et al., 2018). In the field, the inoculation of corn with $A$. brasilense by sprinkling led to a greater stem growth and plant biomass, compared with treatments using standard seed inoculation and

Table 1. Net photosynthesis (A), stomatal conductance $\left(g_{\mathrm{s}}\right)$, transpiration $(E)$, and leaf temperature (Lt) of the VAT 90212 sugarcane (Saccharum spp.) variety inoculated with five diazotrophic bacteria (Gluconacetobacter diazotrophicus Pal5 $^{\mathrm{T}}$, Nitrospirillum amazonense Cbamc, Herbaspirillum seropedicae HRC54, Herbaspirillum rubrisubalbicans HCC103, and Paraburkholderia tropica $\mathrm{PPe}^{\mathrm{T}}$ ) or fertilized with nitrogen under field conditions in the Brazilian semiarid region, in the 2013-2015 crop cycles ${ }^{(1)}$.

\begin{tabular}{|c|c|c|c|c|c|c|c|}
\hline \multirow[t]{2}{*}{ Treatment $^{(2)}$} & \multicolumn{2}{|c|}{$\mathrm{A}\left(\mu \mathrm{mol} \mathrm{m} \mathrm{m}^{-2} \mathrm{~s}^{-1}\right)$} & \multicolumn{2}{|c|}{$g_{\mathrm{s}}\left(\mathrm{mol} \mathrm{m} \mathrm{m}^{-2} \mathrm{~s}^{-1}\right)$} & \multicolumn{2}{|c|}{$E\left(\mathrm{mmol} \mathrm{m} \mathrm{m}^{-2} \mathrm{~s}^{-1}\right)$} & \multirow{2}{*}{$\begin{array}{c}\mathrm{Lt} \\
\left({ }^{\circ} \mathrm{C}\right)\end{array}$} \\
\hline & Cane-plant & Ratoon-cane & Cane-plant & Ratoon-cane & Cane-plant & Ratoon-cane & \\
\hline SSI & $11.40 \mathrm{Bbc}$ & $17.84 \mathrm{Aab}$ & $0.05 \mathrm{Abd}$ & $0.06 \mathrm{Aab}$ & $1.38 \mathrm{Bc}$ & $2.05 \mathrm{Aab}$ & $33.44 a$ \\
\hline $\mathrm{SSI}+1 \mathrm{ISI}$ & $13.38 \mathrm{Bab}$ & $16.11 \mathrm{Abc}$ & $0.09 \mathrm{Aa}$ & $0.05 \mathrm{Bb}$ & $2.49 \mathrm{Aa}$ & $1.97 \mathrm{Bb}$ & $33.22 \mathrm{ab}$ \\
\hline $1 \mathrm{ISI}$ & $13.52 \mathrm{Ba}$ & $18.83 \mathrm{Aa}$ & $0.06 \mathrm{Abc}$ & $0.07 \mathrm{Aa}$ & $1.77 \mathrm{Bbc}$ & $2.63 \mathrm{Aa}$ & $33.29 \mathrm{ab}$ \\
\hline 2 ISI & 12.98Babc & $15.01 \mathrm{Ac}$ & $0.08 \mathrm{Aab}$ & $0.06 \mathrm{Bab}$ & $2.35 \mathrm{Aab}$ & $2.16 \mathrm{Aab}$ & $32.56 b$ \\
\hline $\mathrm{N}$ fertilization & $11.39 \mathrm{Bbc}$ & $18.01 \mathrm{Aab}$ & $0.06 \mathrm{Abd}$ & $0.05 \mathrm{Aab}$ & $1.51 \mathrm{Bc}$ & $1.96 \mathrm{Ab}$ & $33.22 \mathrm{ab}$ \\
\hline Negative control & $11.35 \mathrm{Bc}$ & $15.63 \mathrm{Ac}$ & $0.04 \mathrm{Ad}$ & $0.05 \mathrm{Ab}$ & $1.33 \mathrm{Ac}$ & $2.06 \mathrm{Bab}$ & $33.58 \mathrm{a}$ \\
\hline CV (\%) & \multicolumn{2}{|c|}{5.63} & \multicolumn{2}{|c|}{3.23} & \multicolumn{2}{|c|}{8.41} & 5.87 \\
\hline
\end{tabular}

${ }^{(1)}$ Means followed by equal letters, uppercase in the line (between cycles) and lowercase in the column (between treatments), do not differ by Tukey's test, at $5 \%$ probability. ${ }^{(2)}$ SSI, standard inoculation by submersion; SSI +1 ISI, standard inoculation by submersion + one inoculation by irrigation system six months after planting; 1 ISI, one inoculation by irrigation system two months after planting; 2 ISI, two inoculations by irrigation system two and six months after planting; $\mathrm{N}$ fertilization, $120 \mathrm{~kg} \mathrm{ha}^{-1}$ urea-N per cycle; and negative control, without inoculation or $\mathrm{N}$ fertilization.

Table 2. Number of leaves and stems, plant height, and stem diameter and yield of the VAT 90212 sugarcane (Saccharum spp.) variety inoculated with five diazotrophic bacteria (Gluconacetobacter diazotrophicus Pal5 ${ }^{\mathrm{T}}$, Nitrospirillum amazonense Cbamc, Herbaspirillum seropedicae HRC54, Herbaspirillum rubrisubalbicans HCC103, and Paraburkholderia tropica $\mathrm{PPe}^{\mathrm{T}}$ ) or fertilized with nitrogen under field conditions in the Brazilian semiarid region, in the 2013-2015 crop cycles $^{(1)}$.

\begin{tabular}{|c|c|c|c|c|c|c|c|c|}
\hline \multirow[t]{2}{*}{ Treatment $^{(2)}$} & \multicolumn{2}{|c|}{ Leaves per plant } & \multicolumn{2}{|c|}{ Plant height (cm per plant) } & \multirow{2}{*}{$\begin{array}{c}\text { Stems } \\
\text { per plant }\end{array}$} & \multirow{2}{*}{$\begin{array}{l}\text { Stem diameter } \\
(\mathrm{cm})\end{array}$} & \multirow{2}{*}{$\begin{array}{c}\text { Yield } \\
\left(\mathrm{Mg} \mathrm{ha}^{-1}\right)\end{array}$} & \multirow{2}{*}{$\begin{array}{c}\text { Yield increase }{ }^{(3)} \\
(\%)\end{array}$} \\
\hline & Cane-plant & Ratoon-cane & Cane-plant & Ratoon-cane & & & & \\
\hline SSI & $9.43 \mathrm{Aa}$ & 7.20Ba & $295.03 \mathrm{Aa}$ & $236.70 \mathrm{Ba}$ & $21.40 \mathrm{~b}$ & $26.81 \mathrm{ab}$ & $141.56 b$ & -0.4 \\
\hline $\mathrm{SSI}+1 \mathrm{ISI}$ & $9.13 \mathrm{Aab}$ & $7.43 \mathrm{Ba}$ & $296.97 \mathrm{Aa}$ & $217.68 \mathrm{Ba}$ & $21.42 b$ & $27.36 \mathrm{a}$ & $148.39 \mathrm{ab}$ & 4.4 \\
\hline $1 \mathrm{ISI}$ & $9.05 \mathrm{Aab}$ & $7.68 \mathrm{Ba}$ & 265.37Aab & $238.50 \mathrm{Ba}$ & $22.76 \mathrm{ab}$ & $27.18 \mathrm{a}$ & $158.23 \mathrm{ab}$ & 11.3 \\
\hline 2 ISI & $9.18 \mathrm{Aab}$ & 7.63Ba & $290.90 \mathrm{Aa}$ & $241.05 \mathrm{Ba}$ & $23.29 \mathrm{a}$ & $25.58 \mathrm{ab}$ & $164.90 \mathrm{a}$ & 16.0 \\
\hline $\mathrm{N}$ fertilization & $8.03 \mathrm{Ab}$ & $7.83 \mathrm{Aa}$ & $256.27 \mathrm{Ab}$ & $235.13 \mathrm{Aa}$ & $22.53 \mathrm{ab}$ & $27.14 \mathrm{a}$ & $170.99 \mathrm{a}$ & 20.3 \\
\hline Negative control & 8.91Aab & $7.65 \mathrm{Ba}$ & $284.63 \mathrm{Aab}$ & $237.25 \mathrm{Ba}$ & $22.43 \mathrm{ab}$ & $25.00 \mathrm{~b}$ & $142.19 b$ & - \\
\hline CV $(\%)$ & \multicolumn{2}{|c|}{7.22} & \multicolumn{2}{|c|}{15.40} & 5.66 & 3.54 & 10.79 & \\
\hline
\end{tabular}

${ }^{(1)}$ Means followed by equal letters, uppercase in the line (between cycles) and lowercase in the column (between treatments), do not differ by Tukey's test, at 5\% probability. ${ }^{(2)}$ SSI, standard inoculation by submersion; SSI + 1 ISI, standard inoculation by submersion + one inoculation by irrigation system six months after planting; 1 ISI, one inoculation by irrigation system two months after planting; 2 ISI, two inoculations by irrigation system two and six months after planting; $\mathrm{N}$ fertilization, $120 \mathrm{~kg} \mathrm{ha}^{-1}$ urea-N per cycle; and negative control, without inoculation or $\mathrm{N}$ fertilization.

${ }^{(3)}$ Percentage of yield increase compared with the negative control treatment. 
absolute controls (Costa et al., 2015). However, for inoculation using the drip irrigation system, there is no known available data.

The parameters number of stems and stem diameter and yield were not affected by the interaction of the two factors of the studied factorial arrangement. The plants that received two applications of inoculants by the irrigation system stood out regarding number of stems per plant in the cane-plant cycle, when compared with those under SSI and SSI + 1 ISI. The N fertilization, SSI + 1 ISI, and 1 ISI treatments showed more stems per plant than the absolute control. Regarding stem yield, $\mathrm{N}$ fertilization and 2 ISI achieved higher averages than the absolute control and SSI. There was an increase of 20.3 and $16.0 \%$ in this parameter for $\mathrm{N}$ fertilization and 2 ISI, respectively, compared with the absolute control. The 1 ISI and SSI + 1 ISI treatments did not differ from all others according to Tukey's test, at $5 \%$ probability.

The high efficiency of bacterial inoculation by the SSI method has already been reported in Brazil (Silva et al., 2009; Schultz et al., 2014), but in different edaphoclimatic conditions than those of the Brazilian semiarid region. In this environmental condition, the best way to deliver diazotrophic bacteria into sugarcane in the field seems to be inoculation by water via the drip irrigation system, especially when two inoculations are applied. The inoculation of soybean [Glycine max (L.) Merr.] Bradyrhizobium by drip water is an efficient strategy for microbial inoculation in Syria, in a location with an arid climate (Janat \& Kurdali, 2008), which is in alignment with the present study and indicates the efficiency of this irrigation strategy in drylands.

The substitution of $\mathrm{N}$ fertilization by inoculation by drip irrigation allows reducing $\mathrm{N}_{2} \mathrm{O}$ emission, which is dependent on the $\mathrm{N}$ fertilizer applied in the field (Signor \& Cerri, 2013). Economically, the adoption of this technology by farmers should reduce production costs and increase yields (Pereira et al., 2019). In the present study, the obtained yield was the same as that by the application of $120 \mathrm{~kg}$ urea-N per year.

It should be noted that there is a lack of knowledge of inoculation strategies through irrigation systems in Brazilian drylands. The results obtained in the present study show that the delivery of the diazotrophic bacterial consortium through the drip irrigation system, using two inoculant applications, is the most suitable to promote sugarcane yield in the evaluated environmental conditions, since this treatment resulted in the same yield as that of $120 \mathrm{~kg} \mathrm{ha}^{-1}$ urea-N per year.

\section{Acknowledgments}

To Instituto Nacional de Ciência e Tecnologia (INCT)-Microrganismos Promotores do Crescimento de Plantas Visando à Sustentabilidade Agrícola e à Responsabilidade Ambiental (MPCPAgro) of Conselho Nacional de Desenvolvimento Científico e Tecnológico (CNPq)/Fundação Araucária-STI/ Coordenação de Aperfeiçoamento de Pessoal de Nível Superior (Capes), for financial support (process number 465133/2014-4); and to Empresa Brasileira de Pesquisa Agropecuária (Embrapa), for financial support (project number 02.11.01.009.00.00).

\section{References}

ALLEN, R.G.; PEREIRA, L.S.; RAES, D.; SMITH, M. Crop evapotranspiration: guidelines for computing crop water requirements. Rome: FAO: 1998. 300p. (FAO. Irrigation and Drainage Paper, n.56).

BENEDUZI, A.; MOREIRA, F.; COSTA, P.B.; VARGAS, L.K.; LISBOA, B.B.; FAVRETO, R.; BALDANI, J.I.; PASSAGLIA, L.M.P. Diversity and plant growth promoting evaluation abilities of bacteria isolated from sugarcane cultivated in the South of Brazil. Applied Soil Ecology, v.63, p.94-104, 2013. DOI: https://doi.org/10.1016/j.apsoil.2012.08.010.

CLAESSEN, M.E.C. (Org.). Manual de métodos de análise de solo. 2.ed. rev. e atual. Rio de Janeiro: Embrapa-CNPS, 1997. 212p. (Embrapa-CNPS. Documentos, 1).

CONAB. Companhia Nacional de Abastecimento. Séries históricas das safras. Available at: $<$ https://www.conab.gov.br/ info-agro/safras/serie-historica-das-safras $>$. Accessed on: June 9 2017.

COSTA, R.R.G.F.; QUIRINO, G. da S.F.; NAVES, D.C. de F.; SANTOS, C.B.; ROCHA, A.F. de S. Efficiency of inoculant with Azospirillum brasilense on the growth and yield of second-harvest maize. Pesquisa Agropecuária Tropical, v.45, p.304-311, 2015. DOI: https:/doi.org/10.1590/1983-40632015v4534593.

GAULT, R.R.; BERNARDI, A.L.; THOMPSON, J.A.; ANDREWS, J.A.; BANKS, L.W.; HEBB, D.M.; BROCKWELL, J. Studies on alternative means of legume inoculation: appraisal of application of inoculant suspended in irrigation water (water-run inoculation). Australian Journal of Experimental Agriculture, v.34, p.401-409, 1994. DOI: https://doi.org/10.1071/EA9940401.

JANAT, M.; KURDALI, F. Assessment of injection of liquid rhizobial inoculum and traditional inoculation of soybean under furrow and drip irrigation. Agrochimica, v.52, p.1-11, 2008.

MEDEIROS, C.D.; OLIVEIRA, M.T.; RIVAS, R.; BALDANI, J.I.; KIDO, E.A.; SANTOS, M.G. Gas exchange, growth, and 
antioxidant activity in sugarcane under biological nitrogen fixation. Photosynthetica, v.50, p.519-528, 2012. DOI: https:/doi.org/10.1007/s11099-012-0059-x.

PEREIRA, W.; SOUSA, J.S.; SCHULTZ, N.; REIS, V.M. Sugarcane productivity as a function of nitrogen fertilization and inoculation with diazotrophic plant growth-promoting bacteria. Sugar Tech, v.21, p.71-82, 2019. DOI: https:/doi.org/10.1007/ s12355-018-0638-7.

SANTOS, H.G. dos; JACOMINE, P.K.T.; ANJOS, L.H.C. dos; OLIVEIRA, V.A. de; LUMBRERAS, J.F.; COELHO, M.R.; ALMEIDA, J.A. de; CUNHA, T.J.F.; OLIVEIRA, J.B. de. Sistema brasileiro de classificação de solos. 3.ed. rev. e ampl. Brasília: Embrapa, 2013. 353p.

SANTOS, S.G. dos; CHAVES, V.A.; RIBEIRO, F. da S.; ALVES, G.C.; REIS, V.M. Rooting and growth of pregerminated sugarcane seedlings inoculated with diazotrophic bacteria. Applied Soil Ecology, v.133, p.12-23, 2019a. DOI: https:/doi.org/10.1016/j.apsoil.2018.08.015.

SANTOS, S.G. dos; RIBEIRO, F. da S.; ALVES, G.C.; SANTOS, L.A.; REIS, V.M. Inoculation with five diazotrophs alters nitrogen metabolism during the initial growth of sugarcane varieties with contrasting responses to added nitrogen. Plant and Soil, p.1-20, 2019b. DOI: https:/doi.org/10.1007/s11104-019-04101-1.

SANTOS, S.G. dos; RIBEIRO, F. da S.; FONSECA, C.S. da; PEREIRA, W.; SANTOS, L.A.; REIS, V.M. Development and nitrate reductase activity of sugarcane inoculated with five diazotrophic strains. Archives of Microbiology, v.199, p.863873, 2017. DOI: https:/doi.org/10.1007/s00203-017-1357-2.

SCHULTZ, N.; SILVA, J.A. da; SOUSA, J.S.; MONTEIRO, R.C.; OLIVEIRA, R.P.; CHAVES, V.A.; PEREIRA, W.; SILVA, M.F. da; BALDANI, J.I.; BODDEY, R.M.; REIS, V.M.; URQUIAGA, $\mathrm{S}$. Inoculation of sugarcane with diazotrophic bacteria. Revista Brasileira de Ciência do Solo, v.38, p.407-414, 2014. DOI: https:/doi.org/10.1590/S0100-06832014000200005.

SIGNOR, D.; CERRI, C.E.P. Nitrous oxide emissions in agricultural soils: a review. Pesquisa Agropecuária Tropical, v.43, p.322-338, 2013. DOI: https:/doi.org/10.1590/S198340632013000300014.

SILVA, M.F. da; OLIVEIRA, P.J. de; XAVIER, G.R.; RUMJANEK, N.G.; REIS, V.M. Inoculantes formulados com polímeros e bactérias endofíticas para a cultura da cana-deaçúcar. Pesquisa Agropecuária Brasileira, v.44, p.1437-1443, 2009. DOI: https:/doi.org/10.1590/S0100-204X2009001100010.

SIMÕES, W.L.; CALGARO, M.; COELHO, D.S.; SOUZA, M.A. de; LIMA, J.A. Respostas de variáveis fisiológicas e tecnológicas da cana-de-açúcar a diferentes sistemas de irrigação. Revista Ciência Agronômica, v.46, p.11-20, 2015.

SIMÕES, W.L.; OLIVEIRA, A.R. de; REIS, V.M.; PEREIRA, W.; LIMA, J.A. Aplicação de bactérias diazotróficas via sistema de irrigação para fixação biológica de nitrogênio na cana-deaçúcar. Energia na Agricultura, v.33, p.45-51, 2018. DOI: https:/doi.org/10.17224/EnergAgric.2018v33n1p45-51.

URQUIAGA, S.; XAVIER, R.P.; MORAIS, R.F. de; BATISTA, R.B.; SCHULTZ, N.; LEITE, J.M.; SÁ, J.M. e; BARBOSA, K.P.; RESENDE, A.S. de; ALVES, B.J.R.; BODDEY, R.M. Evidence from field nitrogen balance and ${ }^{15} \mathrm{~N}$ natural abundance data for the contribution of biological $\mathrm{N}_{2}$ fixation to Brazilian sugarcane varieties. Plant and Soil, v.356, p.5-21, 2012. DOI: https:/doi.org/10.1007/s11104-011-1016-3. 